Dear Author,

Please, note that changes made to the HTML content will be added to the article before publication, but are not reflected in this PDF.

Note also that this file should not be used for submitting corrections. 


\title{
Joint venture schemes in Limpopo Province and their outcomes on a7 Smallholder farmers livelihoods
}

\author{
Q6 Everisto Mapedza ${ }^{\text {a, * }}$, Barbara van Koppen ${ }^{a}$, Pinimidzai Sithole ${ }^{\text {b }}$, Magalie Bourblanc ${ }^{c}$ \\ a International Water Management Institute (IWMI), Southern Africa Office, Pretoria, South Africa \\ ${ }^{\mathrm{b}}$ Pegasys Strategy and Development, Pretoria, South Africa

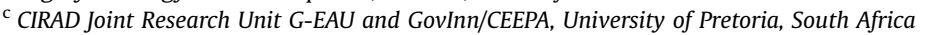

\section{A R T I C L E I N F O}

\section{Article history:}

Received 28 March 2015

Received in revised form 3 October 2015

Accepted 19 October 2015

Available online $\mathrm{xxx}$

\section{Keywords:}

Smallholder

Joint venture

Irrigation

Livelihoods

Gender

\begin{abstract}
A B S T R A C T
Joint Venture schemes based on the floppy irrigation technology are being promoted in the postApartheid South Africa's Limpopo Province. Access to land and water resources in South Africa are largely viewed as a mechanism for re-dressing the Apartheid injustices. This research was part of a broader applied research to help inform irrigation practise in the Limpopo Province. The research used literature review, key informant interviews and a questionnaire survey. The overall research question sought to understand how the Joint Venture Schemes had benefited the smallholder farmers. This paper argues that the joint venture partnership created a new injustice. Firstly, the Joint Venture Scheme design is fundamentally a bad idea which disempower farmers not only to water access but also land as well. The choice of the 'efficient' floppy irrigation technology was made by the state and entailed that land had to be managed as a single unit. In order to make more effective use of this highly sophisticated new technology, the smallholder farmers also needed to go into a joint venture partnership with a white commercial farmer. By virtue of signing the Joint Venture agreement the farmers were also forfeiting their land and water rights to be used for crop production. The smallholder farmers lost access to their water and land resources and were largely relegated to sharing profits - when they exist - with hardly any skills development despite what was initially envisaged in the Joint Venture partnership. Secondly, the implementation of the JVS has been skewed from the start which explains the bad results. This paper further shows how the negative outcomes affected women in particular. As the smallholder farmers argue the technological options chosen by the state have excluded both male and female farmers from accessing and utilising their land and water resources in order to improve their livelihoods; it has entrenched the role of the state and the private interests at the expense of the smallholder male and female farmers in whose name the irrigation funding was justified. The paper concludes by offering recommendations on how joint venture schemes can be genuinely participatory and meaningfully address the rural livelihoods.
\end{abstract}

() 2015 Published by Elsevier Ltd.

1474-7065/@ 2015 Published by Elsevier Ltd. 
within the Limpopo Province of South Africa.

Agriculture plays a key role for rural communities in subSaharan Africa. In South Africa, according to the National Development Plan (2011) agriculture is contributing towards economic growth and improved livelihoods for the poor (RSA, 2011). Whilst the South African economy is largely industry based with agriculture contributing 3\% of its Gross Domestic Product, some rural livelihoods are highly dependent on agriculture especially in the communal lands which are former Bantustans. Water is central to South Africa's increased agricultural productivity. The importance of irrigation as contributing to food security has been highlighted (Van Averbeke et al., 2011). However, the country is reaching its physical water scarcity so competition between agriculture and urban industrial uses is increasing. Most of its available water resources have been exploited, taking into account the water requirements for ecosystem services as well. Molden et al. (2007) distinguish physical from economic water scarcity. Economic water scarcity is when the physical water resources are available but the limited financial resources make it impossible to exploit the available water resources as is the case in a number of the subSaharan African countries. Physical water scarcity is when a country is running out of the physical water resources for use as opposed to the financial resources for accessing the physical water resources. South Africa is ranked as the 30th driest country in the world (DWA, 2013).

In an effort to make the most of the limited water resources, efficient irrigation technologies are being proposed as a solution for making every drop count. Water use efficiency is therefore central in increasing food production. This discourse is strong and is also imposed on smallholders, in spite of the stated intentions of the distributive water allocation reform has been very slow with $99.5 \%$ of the rural households only accessing $5 \%$ of the available water in South Africa (Cullis and Van Koppen, 2008).

This paper uses the case of the Limpopo Province of South Africa which pursued the water saving technologies in former smallholder schemes with the hope of increasing water use efficiency while maintaining agricultural productivity. The paper will further analyse how the pursuit of water saving technologies in the form of floppy irrigation technology which was meant to increase water use efficiency seemed to have the opposite effect for the smallholders. Rather than realising the envisaged benefits from the water use efficient floppy irrigation system, the joint venture scheme resulted in the displacement of smallholder land owners. The justification for the investment in agriculture in the former Bantustans (now communal areas) was meant to enhance benefits accruing to the communal area farmers. The physical water scarcity narrative is a recognized way of framing the relation to water resources at the national level. It is now being used in our case as an instrument for disempowering the smallholder farmers in the Limpopo Province.

This paper will therefore use the Joint Venture Scheme in the Limpopo Province of South Africa to critique the nature of the technology used, look at who is benefiting, also from the various other uses of water than irrigation, who is making the rules and what are the sustainability implications. All these will be viewed within the gender lens to see their implications for men and women in the study areas. Practical recommendations will then be made to provide solutions and the way forward.

\section{Study area description}

The study was conducted in two Joint Venture Schemes (JVS) in the Limpopo Province of South Africa as shown in Fig. 1.

The two schemes are Mogalatsane and Setlaboswane which are downstream of the Flag Boschielo Dam. The schemes are part of a cascade of irrigation schemes along the Olifants River downstream of the Flag Boschielo Dam. The schemes were traditionally operated by individual farmers in the pre-1994 period. The state assisted with inputs, ploughing and extension with the individual farmers working on their individual pieces of land. Mogalatsane has a total of 133 ha for the 99 farmers with Setlaboswane having a total of 115 ha for the 96 farmers. The high percentage of women members is related to the demography and the fact that crop cultivation has traditionally been a women's domain. The majority of the famers in the JVS are female. This is mainly due to most of the males moving to urban area for employment. In South Africa, $60 \%$ of the population is based in urban areas. The survey results show that in Mogalatsane $64 \%$ of the households were female headed.

In Setlaboswane the trend was the same with $63 \%$ of the households being female headed and the remaining $37 \%$ being male headed. Table 1 below sums the numbers on the two case study sites.

The two case schemes were selected from a total of 5 schemes within the upper part of the Flag Boschielo schemes whose total irrigated area amounts to 500 ha which all separately had JVS partnership with Arthur William Creighton (AWC). The five schemes form a cascade along the Olifants River and are namely Petwane, Elandskraal, Mogalatsane, Kolokotela and Setlaboswane all within the Greater Serkhukhune District Municipality. Fig. 2 shows the cascade of the schemes along the Olifants River including other schemes beyond the five Flag Boschielo schemes.

The Joint Venture schemes agreements were signed in 2008 and the Memorandum of Agreements (MoAs) ran for 3 years. These were part of a broader vision to revitalise irrigation within the Limpopo Province. The Joint Venture Schemes which heavily relied on the use of the Strategic Partner evolved administratively since it was first mooted in 2001 with little or no consultation with the farmers or the civil society (Derman and Hellum, 2009). The underlying assumption was that this was a good model which would see the smallholder farmers getting profitable and functioning farms at the termination of the lease agreement (Derman et al., 2008). Joint venture schemes were further perceived as enabling the smallholder farmers in making a footstep into commercial farming (Mayson, 2003; Veldwisch, 2004; Van Koppen, 2009).

\section{Materials and methods}

The study in the two schemes began as part of the Challenge Program of Water and Food (CPWF) which began from 2010 to 2014 and was hosted by the International Water Management Institute (IWMI). The first method used was a literature review which looked at what had already been published as well as grey literature and reports. The second approach entailed key informant interviews conducted with researchers and practitioners in agriculture in both the national and provincial governments. Key informant interviews were also conducted with current and past committee members of the Joint Venture Schemes as well as with a representative of the Joint Venture partner and other knowledgeable traditional leaders and farmers.

The study also conducted a questionnaire survey with a total of 49 farmers being interviewed. This comprised a sample of $25 \%$ of the total of 195 farmers in both Mogalatsane and Setlaboswane irrigation schemes who were randomly selected. Out of the sample, 25 farmers were from Mogalatsane with the remainder of 24 coming from Setlaboswane scheme. The research findings were also presented to the Limpopo Department of Agriculture and other stakeholders in Polokwane on 17 October 2014. 


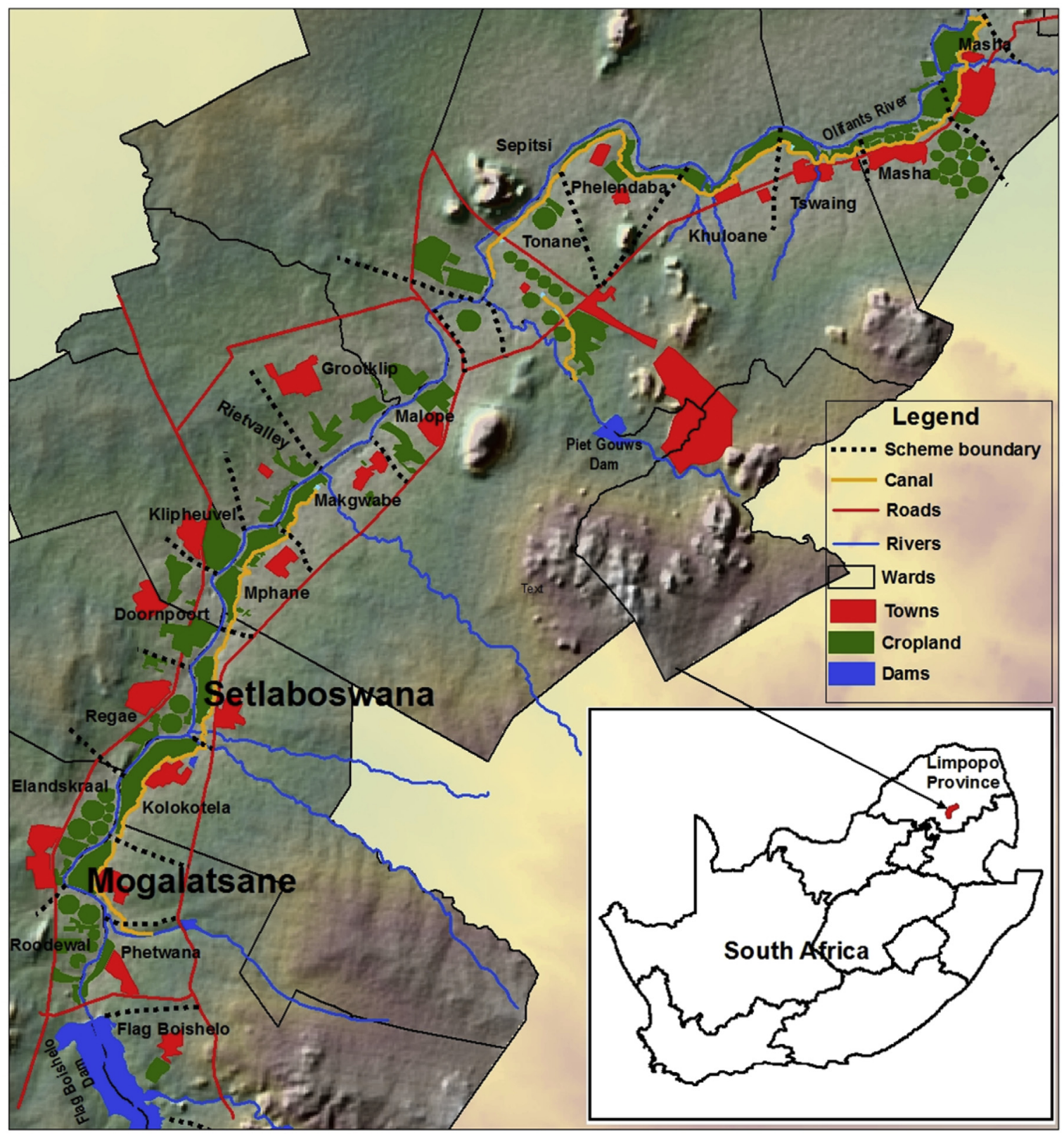

66

67

68

69

70

71

72

73

74

75

76

77

78

79

80

81

82

83

84

85

86

87

88

89

90

91

92

93

94

95

96

97

98

99

100

101

102

103

104

105

106

107

108

109

110

111

112

113

114

115

116

117

118

Prior to independence in 1994, the smallholder farmers were using gravity irrigation with each farmer controlling their individual plot. The parastatal Agricultural and Rural Development 


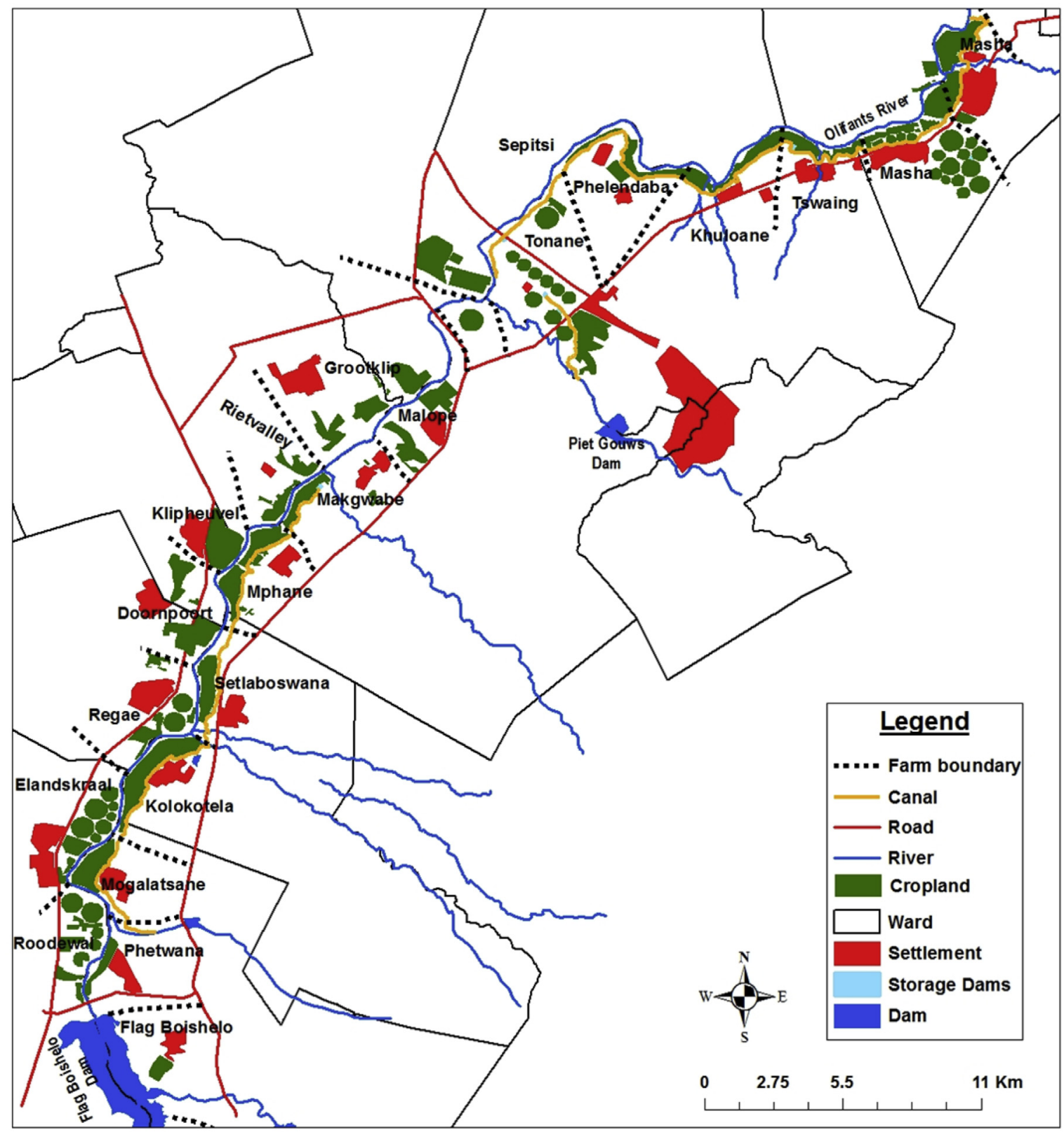

Fig. 2. Irrigation schemes along the Olifants River.

Corporation provided inputs and extension support and training, organized the irrigation, and facilitated the marketing to cooperatives in the white areas. However, with the new joint venture the use of gravity irrigation was abandoned based on the "water scarcity' narrative which encourages more efficient use of water in agriculture. Moreover, the assumption was that the smallholder farmers would learn from the joint venture partner who would transfer management of the farm to the smallholder farmers. The Joint Venture proposal also dictated the amalgamation of the small individual plots to form one big farm to enjoy economies of scale and more efficient use of large machinery such as tractors and combine harvesters. Yet, increased productivity in Asia has demonstrated that land does not seem to be concerned with economies of scale. A land tenure review in the region, more precisely in Zimbabwe drawing on comission visits to Botswana and Kenya (Rukuni Commission, 1994), also clearly demonstrated that unlike in industrial production agricultural production did not seem to enjoy economies of scale.

Whilst the design sounded reasonable, practice on the ground played out differently. The state was pushing for the floppy irrigation technology which was newly developed by the local irrigation equipment business and was argued to be more efficient as it uses forty percent less water than gravity irrigation. Whilst farmers mention that they were consulted on technology, they argue that the consultation was more of promotion of the floppy technology which was argued, could be easily activated and switched off from as far as Marble Hall which is about $40 \mathrm{~km}$ away using a mobile phone. According to the manufacturer "Floppy Sprinkler has developed very efficient sprinkler irrigation technology. This water saving and energy efficient technology is used in sustainable food production in the agricultural industry. International large scale irrigation projects are using this technology." (Floppy Sprinkler website http://www.floppysprinkler.com/accessed on 28 March 2015). With limited technological knowledge the farmers simply 
went along the technological choice which the state was going to invest in before the joint venture scheme began. Yet one needs to consider the choice for such a sophisticated technology in the broader context of the Limpopo Province which has the highest level $(17.3 \%)$ of people aged 20 and above without education as compared to the rest of South Africa.

Limpopo Province within South Africa also has the highest level of unemployment at 38.9\% (Statistics South Africa, 2011) yet the Joint Venture Partner preferred capital intensive production with big tractors, big combine harvesters with the chemical spraying being carried out by a small aeroplane. Such technological imposition would also entail that the smallholder farmers would not develop any capacity. The fact that the farming was capital intensive and was not accompanied by smallholder farmers skills transfer since most of the equipment operators were brought in from the other farms owned by the joint venture partner. Clause 1.2.2 of the Joint Venture Memorandum of Agreement specifically stipulates that the duty to: "train the farmers and transfer the required skills to empower them to be able to operate the Irrigation Scheme, themselves, in the long term which includes training in the areas of finance, quality control, marketing, management, operational, technical and business administration." In practice only five people from each of the scheme were trained. These comprised two trained in pump operation, two in Health and safety issues and one person trained on operating the floppy irrigation system. Initially it was hoped agriculture would help address unemployment since it was argued that for every R1 million 8 jobs are created in mining whilst agriculture created $40-50$ jobs for every R1 million investment (De Lange, 2004). In our case, the Limpopo Department of Agriculture allocated the revitalization of irrigation R248 million between 2005 and 2007 (Tapela, 2008). Yet, in practise very little local part time employment for about fifty people was created due to the qualifications criteria and the capital intensive nature of the farming activities. The Farm Manager for the JVS Partner was very proud that he was one of the three people in South Africa who could operate the Floppy Irrigation system. The smallholder farmers were so angry with the low levels of employment and lack of dividends so much that they dismissed their own committee and replaced it with an entirely new one.

\subsection{Hardly any benefits}

The Joint Venture Scheme (JVS) model was based on the written agreement that the JVS partner would bring all the inputs and expertise. After marketing the farm produce all expenses incurred would be deducted with the profits being shared equally between the JVS partner and the communities. The communities would then decide what to do with their dividend. It is also important to note here that the broader Limpopo Province has the lowest average household income at R57 000 (Statistics South Africa, 2011).

In both Mogalatsane and Setlaboswane the smallholder farmers did not get dividends and the expenses including water and electricity costs were not presented to the farmers. At the end of the farming season the commercial farmer declared that he had made a loss and that there were no dividends to be shared. The memorandum of Agreement's clause 1.2.1 states that the partners will "Operate the Irrigation Scheme, as part of the Limpopo Department of Agriculture, to its optimum potential capacity, on a profitable commercial basis." However the JV partner was not able to produce commercially and went on declaring losses for the 3 year term of the Memorandum of Agreement. The exception was one year in Mogalatsane where each farmer got R2, 000 in one year. In Setlaboswane the community decided to sue the Joint Venture partner. On hearing of the pending legal suit, the Joint venture partner offered a small amount to each farmer which was refused. The legal suit is still pending with the major setback for the smallholder farmers being funds to pay the lawyers to pursue the case in court.

Most of the farmers failed to understand why after a year of cultivation and seeing all the trucks ferrying produce to the market the joint venture partner simply declared a loss. Most women were reminiscing about the past when in addition to their plot produce, they would also have vegetable gardens along the irrigation canals. Under the joint venture scheme women could no longer get vegetables as well. In fact the joint venture partner had guards at all the gates so you had to have permission to even visit 'your land.' In the neighbouring Kolokotela Scheme the Farmers Committee Chairman remarked "the strategic partner (Arthur) is a crook ... if we are indeed partners, we must talk face to face, and not through intermediaries." 1

The commercial crop cultivation of potatoes and other commercial crops have also been argued to be some form of soil mining before the land is then handed to the smallholder farmers without any benefits. What angered the residents of both Mogalatsane and Setlaboswane is that they were left with huge bills for the water that was used to irrigate the crops. The assumption was that water and electricity used for irrigation should have been paid for as part of the input costs. After the contracts, farmers were left with soils which were poorer and water and electricity bills to pay which were said to be over 300,000 South African Rands.

\subsection{Losing multiple water uses and livelihood benefits}

Prior to the establishment of the Joint Venture Partnership the smallholder farmers, especially women, would use the water in the canals for a range of uses. Women would be able to grow vegetables along the canals. Women were also able to do some of their laundry along the canals. Cattle also got water from the canals. This is what the FAO has also observed worldwide, and now seeks to address from the planning phase onwards through 'Multiple use water services' (MUS). However, with the new Floppy sprinkler irrigation it was no longer possible to do laundry or even cultivate vegetables. Two of the farmers were excluded from the joint venture partnership since their land was not well aligned with the design of the floppy technology. Under the Joint Venture arrangement monocropping was practised and the smallholder partners now needed permission to visit their land which was now being managed as a single unit. The bundle of benefits from the irrigated land was narrowed to one crop at a time. Despite the narrowing of uses of water, losses were still declared with no benefits accruing the smallholder partners.

Studies by the MUS Group (www.musgroup.net) and an evaluation by Van Koppen et al. (2014) have clearly demonstrated that participatory approaches that build on communities' priorities go beyond a single use and integrate the holistic nature of livelihood requirements. Such multiple water use water services are potentially gender sensitive as they address the different and important requirements which are not addressed with a single use water supply for both women and men.

\subsection{Externally driven rules}

The rules governing the Joint Venture Partnership through the Memorandum of Agreement were crafted by the Limpopo Department of Agriculture (LDA) and the JVS partner. Given their low levels of education the smallholder communities who struggled to speak English mentioned that they believed that the LDA

\footnotetext{
1 "Mpheane ke Aurthur ka gore o romela batho bakeng sa garwe. Ditaba ditswa mahlong" in the local language.
} 
and the JVS partner could be trusted to come up with a legally binding document. The lack of rule making powers granted to the community also saw the rules being designed in favour of the JVS partner. One of the key aspects for profit sharing would be joint record keeping so that in the event of losses being declared, all parties would be well aware of the basis of such declaration. In both schemes the JVS partner did not bother to share the expenditure and income records with the smallholder partners. The Committee Members in both Mogalatsane and Setlaboswane attempted to have access to such records. Their attempts were resisted and even their presence in the field office was resisted as they needed permission to access the offices.

The LDA who were supposed to be an interlocutor between the two partners also seem to have sided with the JVS partner. However, in practice, the lack of transparency gave rise to many uncertainties and rumours. During the field research it was insinuated that some of their staff might even have connived with JVS partner at the expense of the smallholder farmers. One of the cited examples was when the Affirmative Action was also pronounced in the agricultural sector. This saw one middle class black becoming a joint partner with the JVS partner under the Black Economic Empowerment in the Agriculture sector (AgriBEE) The new partner had no farming background and this was seen as a ruse for not paying the dividends to the smallholder partners. Even if there was nothing untoward about the arrangements, the fact that there was no transparency in how these were done, left the smallholder farmers to suspect foul play. One former committee member in Mogalatasane remembered how they had been told by the Limpopo Department of Agriculture officials how some farmers involved in the JVS would be rewarded with huge sums of money - which never materialised once they had agreed to the JVS partnership.

With the state through the LDA perceived not to be representing the interests of the smallholder farmers, the smallholder farmers felt seriously disadvantaged, something that seems to be confirmed by the terms of reference of the MoA, the absence of monitoring activity pertaining the implementation of the agreement and the lack of enforcement provision. In a Focus Group Discussion held on 21 October 2011 the farmers remarked that "the problem is that the strategic partner calls the shots by deciding on the declaration of losses; crops to plant; on labour recruitment and how much to pay labourers without negotiating; and does not consult the community, not even the people elected by the community".

\subsection{Lack of sustainability}

Sustainability is one of the key aspects for agricultural technological interventions. Sustainability is defined as "practices that meet current and future societal needs for food and fibre, for ecosystem services, and for healthy lives, and that do so by maximizing the net benefit to society when all costs and benefits of the practices are considered" (Tilman et al., 2002). The Limpopo Department of Agriculture's in-field irrigation technology policy, 2005 claiming that it would also use the "ease of management, repair/replacement and maintenance of the technology" as a criterion to choose the final technology to be installed (cf. Van Koppen, 2008; Denison and Manona, 2008). In both Mogalatsane and Setlaboswane the technological options were well beyond the comprehension of the farmers thereby engraining strong doubts on the sustainability of the technology. The use of big machinery including small planes for crop spraying are well beyond the smallholder farmers most of whom did not even have assets such as ox-drawn carts. The high level of the technology was then used to justify their exclusion in using the equipment. That was expensive equipment which needed qualified operators. By virtue of deciding on a particular technology, this was entrenching the exclusion process which was justified on the grounds of efficiency and increased productivity - which never materialised for the smallholder farmers. This clearly demonstrates that technology is not socially, economically, politically or gender neutral. Women's vegetable gardens, for instance, were not prioritised in water allocation with the focus being on irrigated mono crops.

One of the concerns of the smallholder farmers was that they were not seeing any dividends. What made this more painful for the smallholder farmers was that the state had invested a lot of money on establishing the Floppy Irrigation system, fencing, and building of farm sheds in the name of the smallholder farmers. All this investment by the state was benefiting the JVS partner rather than the community. Feeling disempowered and unable to get recourse through the state support most the joint venture scheme moved to what Scott (1985) calls 'weapons of the weak.' They decided to destroy the floppy sprinkler infrastructure and burn the control room where the computers were housed. The transformers for the JVS partners were also destroyed as well. It was only Setlaboswane, through the efforts of connections to the lawyers in Johannesburg which decided to sue the JVS partner. Lack of resources to pursue the legal recourse seems to be now hampering their pursuit of such recourse.

\section{Conclusion and recommendations}

Whilst the state had declared good intentions with the Joint Venture Schemes the playout at the schemes seem to have yielded some undesirable outcomes for the smallholder farmers which are now undermining sustainability. The state through the Limpopo Department of Agriculture was committed to refurbishing the irrigation infrastructure. Whilst this is commendable, this has to be aligned with efforts to address the institutional and gender aspects of the way forward for the joint venture scheme in order to obtain positive outcomes. Institutional sustainability was also undermined since the focus was on the hardware with very little attention to the social and contextual issues (De Lange, 2004). Whilst it was noted that social and institutional aspects needed to be addressed at the same time as the hardware, in practice this seem to have largely been done half-heartedly. For instance, the choice of the technology had already been pre-determined and the farmer consultation sounded more like manipulation rather than genuine engagement (Arnstein, 1969). A few dissenting voices even within the Limpopo Department of Agriculture were ignored and even undermined. Institutional development and capacity development requires an investment of time and human resources that policymakers are rarely willing to invest although it has been proven that this could develop social capital and result in institutions which are robust and sustainable (Ostrom, 1990; Oakerson, 1992).

The main issue that needs to be addressed is to see the farmers as the key decision makers who are empowered and provided with options to enable them to make decisions (cf. Kwashirai et al., 2013 for experiences elsewhere). Although there was a 'consultation' prior to the establishment of the JVS, based on the research findings, this was largely manipulative or resembled what Mandondo (2000) calls 'facipulation.' Facipulation is a combination of an attempt to facilitate and at the same time manipulation which does not address what the local communities really want. This calls for an interdisciplinary research approach which combines irrigation engineering with the social sciences to provide comprehensive irrigation-based solutions. Based on the research the study recommends the following.

\subsection{Technological options}

Farmers need to be seen as citizens (Mamdani, 1996) so that 
they are engaged in a facilitatory manner. Technology should serve the farmers and not the other way round. It is therefore recommended that a suit of technological options be availed to the farmers so that they can choose their preferred option. It is important to empower the farmers to be able to make informed choices.

\subsection{Farmers must benefit}

It is important that the farmers, who have use right to the land see the benefits accruing to them as opposed to the JVS partner. Juxtaposed with the water reform process, this seems like a reversal as the water use was being consolidated into the hands of the white commercial farmer with little benefits to the black land and water rights holders. It is now.

\subsection{Design for multiple uses}

Irrigation need to be designed for multiple uses in order to enhance holistic livelihoods. Multiple uses will also help address the differential water requirements which are gendered. Inclusive participatory planning by both women and men will highlight gendered priorities.

\subsection{Rule making}

Rule making is very important for rural development as the farmers need to have a say in the crafting of the rules. Such a participatory process will then make it much easier to enforce such locally made and relevant rules. Most states attempt to extend beyond their reach (Mapedza and Mandondo, 2002) and end up making rules which they have no capacity to enforce. Decentralized approach to rule making, taking into account the subsidiarity principle, will result in locally respected and enforced rules.

\subsection{Sustainability}

Sustainability of investments in irrigation infrastructure can only be entrenched where there is local ownership. People cannot be developed, they can only develop themselves. This study demonstrates that smallholder farmers need to be empowered to be able to produce sustainably. Sustainability cannot be imposed; it has to be bottom-up. Addressing local ownership will entail that the state should be willing to hand over authority and meaningful decision making powers to the smallholder farmers. Trust has to be developed over time. Recapitalization should be a condition for the JVS partnership agreements.

\section{Uncited references}

Limpopo Department of Agriculture (2005); Water Affairs, 2007.

\section{Acknowledgements}

This paper is based on a research funded by the Challenge Program on Water and Food (CPWF) hosted by the International Water Management Institute (IWMI). This specifically under the Water Governance Project - Limpopo 4 Project whose partners included International Water Management Institute (IWMI), International Center for Water Economics and Governance in Africa Q4 (IWEGA), University of Zimbabwe and WaterNet.

\section{References}

Arnstein, S.R., 1969. A ladder of participation. J. Am. Inst. Planners 35, 216-223.
Cullis, J., Van Koppen, B., 2008. Applying the Gini Coefficient to Measure the Distribution of Water Use and Benefits of Water Use in South Africa's Provinces [Unpublished report]. Department of Water Affairs and Forestry and International Water Management Institute, Pretoria.

De Lange, M., 2004. Limpopo Province Revitalization of Smallholder Irrigation Schemes. Paper presented at an International Water Management Institute (IWMI) workshop held at Silverton, Pretoria, on 7 May.

Denison, J., Manona, S., 2008. Principles Approaches and Guidelines for the Revitalisation of Smallholder Irrigation Schemes. Volume 1 - Rough Guide. Volume 2 - Concepts and Cases. Report No. TT 308/07 and 309/07. Water Research Commission, South Africa.

Department of Water Affairs, Republic of South Africa, 2013. National Water Resource Strategy Second Edition: Water for an Equitable and Sustainable Future. Department of Water Affairs, Pretoria.

Derman, B., Hellum, A., 2009. Government, business and chiefs: ambiguities of social justice through land restitution in South Africa. In: Von BendaBeckmann, F., et al. (Eds.), 2009 Rules of Law and Laws of Ruling. On the Governance of Law. Ashgate.

Derman, B., Lahiff, E., Sjaastad, E., 2008. Strategic questions about strategic partners: challenges and pitfalls in South Africa's new model of land restitution. In: Walker, C., et al. (Eds.), 2008 Land, Memory, Reconstruction and Justice. Perspectives on Land Claims in South Africa.

Floppy Sprinkler, 2015. Floppy Sprinkler accessed on. http://www.floppysprinkler. $\mathrm{com} /$, 28.03.15.

Kwashirai, T., Mapedza, E., Zhou, G., 2013. Decentralising Zimbabwe's water management: the case of Guyu-Chelesa irrigation scheme. Phys. Chem. Earth 66, 139-147.

Limpopo Department of Agriculture, 2005. Infield Irrigation Technology Policy (Polokwane, South Africa).

Mamdani, M., 1996. Citizen and Subject: Contemporary Africa and the Legacy of Late Colonialism. Princeton University Press, Princeton.

Mandondo, A., 2000. Forging (Un)democratic Resource Governance Systems from the Relic of Zimbabwe's Colonial Past. Institute of Environmental Studies, University of Zimbabwe and Centre for International Forestry Research, Mimeo, Harare, Zimbabwe.

Mapedza, E., Mandondo, A., 2002. Co-management in the Mafungautsi Forest Area of Zimbabwe-What Stake for Local Communities? World Resources Institute, Washington.

Mayson, D., 2003. Joint ventures. In: Hall, R. (Ed.), Evaluating Land and Agrarian Reform in South Africa Series. PLAAS, University of the Western Cape, Cape Town. No. 7, September

Molden, D., Frenken, K., Barker, R., de Fraiture, C., Mati, B., Svendsen, M., Sadoff, C., Finlayson, C.M., 2007. Trends in water and agricultural development. In: Molden, D. (Ed.), Water for Food, Water for Life: a Comprehensive Assessment of Water Management in Agriculture. CABI Publishing, Cambridge and International Water Management Institute (IWMI).

Oakerson, R.J., 1992. Analysing the commons: a framework. In: Bromley, D.W. (Ed.), Making the Commons Work. Institute for Contemporary Studies, San Francisco, pp. 3-15.

Ostrom, E., 1990. Governing the Commons: the Evolution of Institutions for Collective Action. Cambridge University Press, Cambridge.

Republic of South Africa (RSA) National Planning Commission, 2011. National Development Plan: Our Future Make it Work. 2030 Vision. National Planning Commission, The Presidency, Pretoria. http://www.npconline.co.za/MediaLib/ Downloads/Home/Tabs/.

Rukuni Commission, 1994. Report of the Commission of Inquiry into the Appropriate Agricultural Land Tenure Systems under the Chairmanship of Professor Mandivamba Rukuni. Government Printers, Harare.

Scott, J.C., 1985. Weapons of the Weak. Everyday Forms of Peasant Resistance Yale University Press, Yale University.

Statistics South Africa, 2011. Census 2011, Census in Brief. Statistics South Africa Pretoria, South Africa.

Tapela, B.N., 2008. Livelihoods in the wake of agricultural commercialisation in South Africa's poverty Nodes: insights from small-scale irrigation schemes in Limpopo Province. In: Development Southern Africa, Special Issue: Living on the Margins, vol. 25. Number 2, (June)

Tilman, T., Cassman, K.G., Matson, P.A., Naylor, R., Polasky, S., 2002. Agricultural sustainability and intensive production practices. Nature 418, 8. August 2002.

Van Averbeke, W., Denison, J., Mnkeni, P.N.S., 2011. Smallholder Irrigation Schemes in South Africa: a Review of Knowledge Generated by the Water Research Commission. Water SA, vol. 37. No. 5 WRC 40-Year Celebration Special Edition 2011.

Van Koppen, B., 2008. Redressing Inequities from the Past from a Historical Perspective: the Case of the Olifants Basin, South Africa. In: Water SA vol. 34 No 4 HELP Special Edition. Pretoria: Water Research Commission.

Van Koppen, B., Smits, S., del Rio, C.R., Thomas, J., 2014. Upscaling Multiple Use Water Services: Accountability in the Water Sector. IWMI/WLE - International Water and Sanitation Centre IRC - Rockefeller Foundation, London: Practical Action.

Veldwisch, G.J.A., 2004. From Rehabilitation to Revitalization: Experiences in the Thabina Irrigation Scheme, Limpopo Province. Paper presented at an IWMI workshop held in Silverton, Pretoria, on 7 May.

Water Affairs, 2007. Water for Growth and Development Strategy (Pretoria, South Africa). 